American Journal of Applied Sciences 7 (5): 609-615, 2010

ISSN 1546-9239

(C) 2010Science Publications

\title{
A Coupled Mathematical Model for a Temperature Dependant Blood Perfusion in Heterogeneous Biological Tissues during Microwave Heating
}

\author{
E.A. Adebile, B.N. Akintewe and K.M. Owolabi \\ Department of Mathematical Sciences, Federal University of Technology, Akure
}

\begin{abstract}
Problem statement: The temperature variation in heterogeneous three layered biological tissues was investigated. Approach: The blood perfusion was considered to be temperature dependent. The heating modalities were taking to go on simultaneously in each of the regions on the one hand and also sequentially in another arrangement. The asymptotic series solution was modified for the three layers and the matching were done at the interface of the regions where there is electric field effect and where there is none. Results: The result revealed there was a clear difference from the temperature pattern when the heating modality was done simultaneously compared to when done sequentially. The thickness of the tissues layer has effect on temperature pattern. Conclusion: A lot of attention must be taken to determine tissue thermophysical properties before therapy was applied. The regional body heating was preferred to spare surrounding normal tissue as against the whole body heating procedure.
\end{abstract}

Key words: Heterogeneous, steady states, Penne's bio heat equation, perfusion

\section{INTRODUCTION}

Hyperthermia has been found to be one of effective therapeutic means of destroying cancerous cells. It's an act of heating the tissue volume to a desired temperature range for a certain period of time. To attain this feat which is tricky since not all tissues in the body respond the same way to heat; various researches have been undertaken. Penne's in 1948 published his seminar study on developing a quantitative basis for describing thermal interaction between perfused blood and tissue. $\mathrm{He}$ did a lot of experiments to measure temperature distribution as a function of radial position in the forearm of nine human subjects. His data showed a temperature differential to three or four degrees between the Skin and the interior arm, which he attributed to the effects of metabolic heat generation and transfer through perfused blood. He then proposed a model describing the effects of both metabolism and blood perfusion on the energy balance within the tissue. El-Dabe et al. (2003) working much later after Penne's and other authors introduced the effect of electromagnetic effect of Microwaves into their model. They used numerical technique to solve their governing equations. Adebile et al. (2006) did an investigation into the uniqueness and existence of self similar solution for the coupled Maxwell's and Penne's Bio heat equations. The criterion for uniqueness and existence of self similar solution was established. Many other studies undertaken by Adebile and Akintewe (2006) and Adebile et al. (2008), has revealed the need for a great care in hyperthemic therapy in an attempt to protect surrounding living tissues for different BioThermophysical properties of biological tissues. Hwang and Lemonier (1995) studied on coupling numerical solutions of bio heat transfer and Maxwell's equations during hyperthermia. They predicted thermal processes within the tissue using steady state bio heat equations which they solved by the finite element method using C-continuity and three nodded isoparametirc elements. This solution was validated by comparing with an analytical solution of a simplified case. They were able to present physically reasonable temperature distribution within the tissue and highlight the advantage of tumors with low perfusion rates during irradiation. Gowrishankar et al. (2004) studied Bio heat transfer requiring evaluation of temporal and spatial distribution of temperature using the Penne's bio heat equation. Transport of heat by Conduction and temperature dependent, spatial heterogeneous blood perfusion was modeled using the transport lattice approach. This method was validated by comparing an analytical Solution for a slab with heterogeneous thermal properties and spatially distributed uniform sink held at constant temperature at the ends. Damage was found to be small even with prolonged skin contact 
to a surface of up to $45^{\circ} \mathrm{C}$. Also revealed was the fact that spatial heterogeneity in skin thermal properties lead to a non uniform temperature distribution during exposure. A realistic two dimensional model of the skin showed that tissue heterogeneity did not lead to a significant local temperature increase when heated by an Iron tip. Liu et al. (2007) studied on the computer modeling of the effect of perfusion on heating patterns in RF tumor ablation. They performed a computer simulation of RF heating using 2 and 3-D finite element analysis. This simulation was systematically modeled on clinically relevant application parameters for a range of inner tumor perfusion and outer normal surrounding tissue perfusion for internally cooled single and cluster electrodes over a range of tumor diameters and RF application times. The computer model demonstrated that perfusion reduced both RF coagulation and the time to achieve thermal equilibrium. Their results show the importance of considering not only the tumor perfusion but also size and background tissue when attempting to predict the effect of perfusion on RF heating and ablation times. Ting-Bo et al. (2009) proposed a theoretical model of the nonlinear propagation in multi-layered tissues for strong focused ultrasound. The Spheroidal Beam Equation (SBE) is utilized to describe the nonlinear sound propagation in each layer tissue and generalized oblique incidence theory is used to deal with the sound transmission between two layer tissues. Kulikov (2009) investigated the mathematical model of the hyperthermy of the multilayer biological structure under the effect of laser emission was proposed. This allows the variation of the electrophysical parameters of the biological structure. $\mathrm{Xu}$ et al. (2009) studied the theoretical analysis of the transfer of heat through skin tissue and closed-form solutions were obtained for simple one-layer Fourier theory based model. Non-Fourier bioheat transfer models for skin tissue are also discussed and various skin cooling technologies summarized Mahjoob and Vafai (2010) gave a comprehensive analysis of bioheat transport through a double layer and multilayer biological media in this study. Analytical solutions were developed for blood and tissue phase temperatures and overall heat exchange correlations, incorporating thermal conduction in tissue and vascular system, blood-tissue convective heat exchange, metabolic heat generation and imposed heat flux, utilizing both local thermal nonequilibrium and equilibriummodels in porous media theory were presented. Investigation to understand heat transfer analysis in biological media is abounding in a bid to provoke further advances in the field of hyperthermia and consequently promoting safety in medical therapy. The present study is to investigate the effect of simultaneous and sequential heating in the layers considered.

Mathematical formulation: The mathematical formulation of the problem under physically reasonable assumptions are presented in order to establish the governing equations of our Mathematical model.

The governing equations: The temperature, electric and magnetic fields are the three dependent variables in the governing equations:

$$
\begin{aligned}
& \overline{\mathrm{T}}=\mathrm{T}(\mathrm{x}, \mathrm{t}) ; \overline{\mathrm{E}}=\mathrm{E}(0, \mathrm{E}(\mathrm{x}, \mathrm{t}), 0) ; \\
& \overline{\mathrm{H}}=\mathrm{H}(0,0, \mathrm{H}(\mathrm{x}, \mathrm{t}))
\end{aligned}
$$

Presented Fig. 1 is a one dimensioned tissue model. In Adebile et al. (2008) and the relevant literature sited there in, the Maxwell's and bio heat equations were given as:

$$
\begin{aligned}
& \frac{\partial \mathrm{H}}{\partial \mathrm{x}}+\varepsilon \frac{\partial \mathrm{E}}{\partial \mathrm{t}}+\sigma \mathrm{E}=0 \\
& \frac{\partial \mathrm{E}}{\partial \mathrm{x}}+\mu_{1} \frac{\partial \mathrm{H}}{\partial \mathrm{t}}=0 \\
& \rho \mathrm{C}_{\mathrm{p}} \frac{\partial \mathrm{T}}{\partial \mathrm{t}}=\frac{\partial}{\partial \mathrm{x}}\left(\mathrm{K} \frac{\partial \mathrm{T}}{\partial \mathrm{x}}\right)+\omega_{\mathrm{b}} \mathrm{C}_{\mathrm{b}} \mathrm{p}_{\mathrm{b}}\left(\mathrm{T}_{\mathrm{b}}-\mathrm{T}\right)+\mathrm{Q}(\mathrm{T})|\mathrm{E}|^{2}
\end{aligned}
$$

Where:

$\rho=$ Density

$\mathrm{C}_{\mathrm{p}}=$ Specific heat capacity

$\mathrm{t}=$ Time

$\mathrm{C}_{\mathrm{b}}=$ Specific heat capacity of blood

$\mathrm{E}=$ Electric field

$\mathrm{X}=$ Space coordinates

$\mathrm{H}=$ Magnetic field

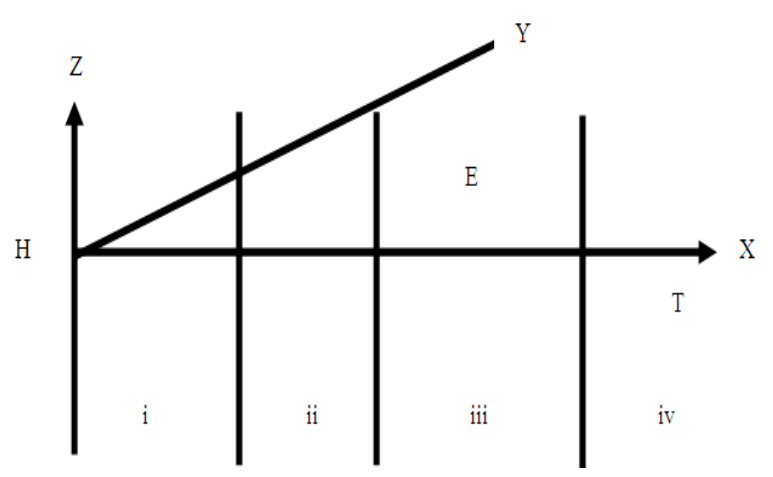

Fig. 1: Multilayered tissue Key: (i) epidermis; (ii) dermis; (iii) subcutaneous; (iv) inner tissue 
Am. J. Applied Sci., 7 (5): 609-615, 2010

$\mathrm{T}=$ Tissue temperature

$\mathrm{T}_{\mathrm{a}}=$ Artery temperature

$\mathrm{T}_{\mathrm{b}}=$ Blood temperature

$\mathrm{T}_{\mathrm{c}}=$ Core temperature

$\mathrm{T}_{\mathrm{w}}=$ Wall temperature

$\mathrm{m}=$ Positive Integer

$\rho_{\mathrm{b}}=$ Density of blood

$\omega_{\mathrm{b}}=$ Blood perfusion rate

$\kappa=$ Thermal Conductivity of tissue

$\mathrm{Q}=$ Body heating coefficient

$\mu=$ Magnetic permeability

$\varepsilon=$ Electric permittivity

$\sigma=$ Electric conductivity

$\mathrm{H}_{\mathrm{o}}=$ Magnetic field in free space upon tissue

$\mathrm{E}_{\mathrm{o}}=$ Electric field in free space upon tissue

$\mathrm{P}_{\mathrm{r}}=$ Prandtl's number

$v=$ Kinematics viscosity

$\mu_{\mathrm{t}}=$ Viscosity of tissue

$\omega=$ Perfusion

In (4), the first term is the energy gradient; the second term presents the energy stored in the tissue while the third term is the blood transport between the tissue and the blood.

Equation 2-4 are subject to the following initial and boundary conditions:

$$
\begin{array}{ccc}
T(x, 0)=\frac{T_{c} x}{L} & T(L, t)=\frac{T_{c}}{T_{b}} & T(0, t)=0 \\
T(0, t)=0=\frac{E_{0} x}{L} & E(L, t)=E_{0} & E(L, t)=E_{0} \\
H(x, 0)=\frac{H_{0} x}{L} & H(L, t)=H_{0} & H(L, t)=H_{0}
\end{array}
$$

where, $\mathrm{L}$, is distance from skin surface to core.

As in Adebile et al. (2008) it was reviewed that physical properties of materials have power law dependence on temperature, so then:

$\mathrm{Q}(\mathrm{T})=\mathrm{T}^{\mathrm{m}}$

Introducing the following non dimensional variables:

$$
\begin{aligned}
& \mathrm{t}^{*}=\frac{\mathrm{t} v}{\mathrm{~L}^{2}} \quad \mathrm{x}=\frac{\mathrm{x}}{\mathrm{L}} \quad \mathrm{T}^{*}=\frac{\mathrm{Tc}}{\mathrm{Tb}} \quad \mathrm{C}_{1}=\frac{\mathrm{C}_{\mathrm{b}}}{\mathrm{C}_{\mathrm{p}}} \\
& \mathrm{E}^{*}=\frac{\mathrm{E}}{\mathrm{E}_{0}} \quad \mathrm{H}^{*}=\frac{\mathrm{H}}{\mathrm{H}_{0}} \rho_{1}=\frac{\rho_{\mathrm{b}}}{\rho} \quad \omega_{1}=\frac{\omega_{\mathrm{b}} \mathrm{L}^{2}}{\mathrm{v}} \\
& \lambda=\frac{\mathrm{L}^{2} \mathrm{~T}_{\mathrm{b}}^{\mathrm{m}-1}\left|\mathrm{E}_{0}\right|^{2}}{v \rho \mathrm{C}_{\mathrm{p}}} \lambda_{1}=\frac{v \varepsilon \mathrm{E}_{0}}{\mathrm{LH}_{0}} \lambda_{2}=\frac{\mathrm{L \sigma E_{0 }}}{\mathrm{H}_{0}} \lambda_{3}=\frac{\mu \varepsilon \mathrm{H}_{0} \sigma}{\mathrm{L} \Sigma_{0}}
\end{aligned}
$$

Hence the dimensionless Maxwell's and Penne's bio heat equation after ignoring the star mark is written as:

$$
\begin{aligned}
& \frac{\partial \mathrm{H}}{\partial \mathrm{x}}+\lambda_{1} \frac{\partial \mathrm{E}}{\partial \mathrm{t}}+\lambda_{2} \mathrm{E}=0 \\
& \frac{\partial \mathrm{E}}{\partial \mathrm{x}}+\lambda_{3} \frac{\partial \mathrm{H}}{\partial \mathrm{t}}=0 \\
& \frac{\partial \mathrm{T}}{\partial \mathrm{t}}=\frac{1}{\operatorname{Pr}}\left(\frac{\partial^{2} \mathrm{~T}}{\partial \mathrm{x}^{2}}\right)+\omega_{1} \mathrm{P}_{1} \mathrm{C}_{1}(1-\mathrm{T})+\lambda|\mathrm{E}|^{2} \mathrm{~T}^{\mathrm{m}}
\end{aligned}
$$

Subject to the non dimensional initial and boundary conditions:

$$
\begin{array}{ccc}
T(x, 0)=\frac{T_{c}}{T_{b}} x & T(1, t)=\frac{T_{c}}{T_{b}} & T(0, t)=0 \\
E(x, 0)=x & E(1, t)=1 & E(0, t)=0 \\
H(x, 0)=x & H(1, t)=1 & H(1, t)=1
\end{array}
$$

\section{MATERIALS AND METHODS}

Method of solution: Steady equations for a single layered temperature dependent perfusion.

Some of the assumptions taken to simplify the model are:

- The rate of blood perfusion is temperature dependent

- $\mathrm{m}=1$

Therefore the steady states Maxwell's and Penne's bio heat equations to be solved are:

$\frac{\mathrm{dH}}{\mathrm{dx}}+\lambda_{2} \mathrm{E}=0$

$\frac{\mathrm{dE}}{\mathrm{dx}}=0$

$\beta \frac{d T}{d x^{2}}+\left(a_{0}+b_{0} T\right)^{n}(1-T)+\lambda|E|^{2} T=0$

$\omega=\left(\mathrm{a}_{0}+\mathrm{b}_{0} \mathrm{~T}\right)^{\mathrm{n}}, \mathrm{a}_{\mathrm{o}}, \mathrm{b}_{\mathrm{o}}, \mathrm{n} \in \mathrm{R}$

Subject to:

$$
\begin{array}{lll}
\mathrm{T}(0)=0 & \mathrm{E}(0)=0 & \mathrm{E}(0)=0 \\
\mathrm{~T}(1)=\frac{\mathrm{T}_{\mathrm{c}}}{\mathrm{T}_{\mathrm{b}}} & \mathrm{E}(1)=1 & \mathrm{E}(1)=1
\end{array}
$$


Equation 12 and 13 are solved to get:

$\mathrm{E}(\mathrm{x})= \begin{cases}0 & \mathrm{x}<\mathrm{a} \\ 1 & \mathrm{x} \geq \mathrm{a}\end{cases}$

This provokes a solution in two regions and supports two methods of heat application during microwave hyperthermia, subtitled Case I and II.

Case I: This is a simultaneous heating procedure within the three heterogeneous layers, while taking cognizance of the two region solution in each layer, as illustrated below:

Simultaneous three-way heating procedure:

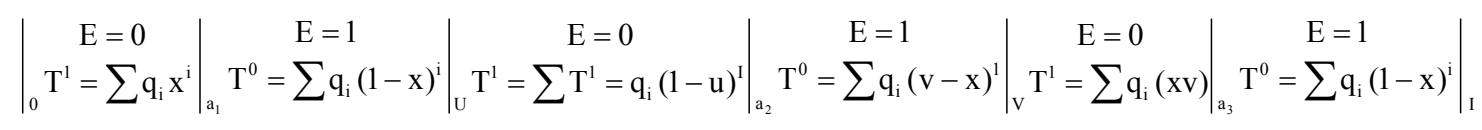

The equations within each layer will be solved subject to the initial and boundary conditions:

$$
\begin{array}{lll}
T(0)=p_{0} & T(u)=q_{0} & \text { for } 0 \leq x \leq U \\
T(u)=P_{0} & T(v)=q_{0} & \text { for } U \leq x \leq V \\
T(v)=p_{0} & T(1)=q_{0}=\frac{T c}{T b} & \text { for } V \leq x \leq 1
\end{array}
$$

Where:

$\mathrm{U}$ and $\mathrm{V} \quad=$ Arbitrary points within the tissue

$\mathrm{a}_{1}, \mathrm{a}_{2}$ and $\mathrm{a}_{3}=$ The matching points in each homogeneous layer

Case II: This heating procedure is done with matching at a point in a sequential order for each of the three layers. This procedure implies three heating arrangements as illustration below:

Heating method 1: Heat application within the first homogeneous layer:

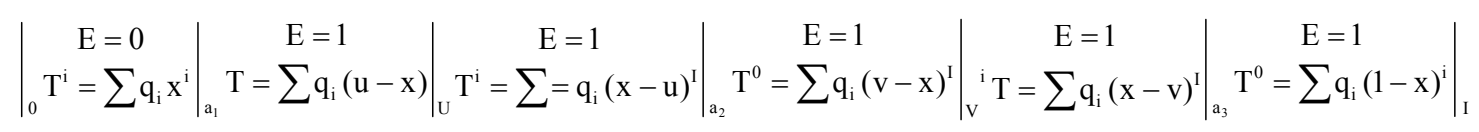

\section{Heating method 2: Heat application within the second homogeneous layer:}

$$
\left.\left|\begin{array}{c|c|c}
E=0 & E=0 \\
T^{1}=\sum q_{i} x^{i}
\end{array}\right| \begin{gathered}
E=0 \\
a_{1}
\end{gathered}\right|^{i}=\left.\sum P_{i}(u-x)^{i}\right|_{U} T^{i}=\sum=\left.P_{i}(u-x)^{I}\right|_{a_{2}} T^{i}=\left.\sum q_{i}(v-x)^{i}\right|_{V} T^{i}=\left.\sum q_{i}(x-v)^{I}\right|_{a_{3}} T^{0}=\left.\sum q_{i}(1-x)^{i}\right|_{I}
$$

\section{Heating method 3: Heat application within the third homogenous layer:}

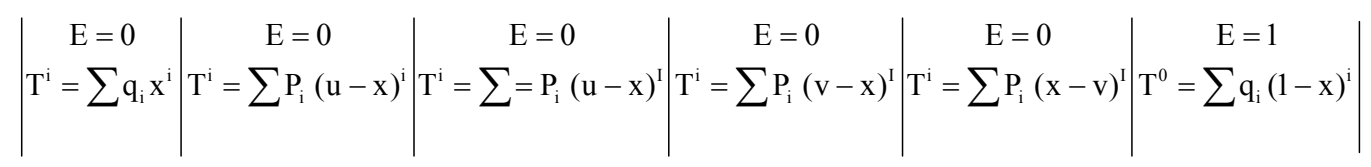

Where:

$\mathrm{U}$ and $\mathrm{V} \quad=$ Arbitrary points within the tissue

$\mathrm{a}_{1}, \mathrm{a}_{2}$ and $\mathrm{a}_{3}=$ The matching points in each homogeneous layer 
The equations within each layer for all three methods will be solved subject to the initial and boundary conditions:

$\mathrm{T}(0)=0, \quad \mathrm{~T}(\mathrm{u})=\mathrm{U}, \quad$ for $\mathrm{O} \leq \mathrm{x} \leq \mathrm{U}$

$\mathrm{T}(\mathrm{u})=\mathrm{U}_{1}, \quad \mathrm{~T}(\mathrm{v})=\mathrm{v}_{1} \quad$ for $\mathrm{U} \leq \mathrm{x} \leq \mathrm{V}$

$\mathrm{T}(\mathrm{v})=\mathrm{v}_{1}, \quad \mathrm{~T}(1)=\frac{\mathrm{T}_{\mathrm{c}}}{\mathrm{T}_{\mathrm{b}}} \quad$ for $\mathrm{V} \leq \mathrm{x} \leq 1$

The equations for the inner and outer regions each layer for the different arrangements are the solved subject to the initial and boundary conditions defined in (21-23) and (12-14) the governing equations. This is shown below.

This provokes a solution in two regions.

For region I, the steady state Penne's bio heat equation to be solved is:

$\beta \frac{d T}{d x^{2}}+\left(a_{0}+b_{0} T\right)^{n}(1-T)=0$

$\mathrm{T}(0)=0$

$\mathrm{T}(\mathrm{a})=\mathrm{h}$

A solution is sought for:

$\mathrm{T}^{\mathrm{i}}=\sum_{\mathrm{i}=1}^{\infty} \mathrm{P}_{\mathrm{i}} \mathrm{x}^{\mathrm{i}} \quad 0 \leq \mathrm{x} \leq \mathrm{a}$

Subject to the matching condition (25) substituting (26) into (24) comparing and collecting the coefficients of, Order $\mathrm{x}^{0}, \mathrm{x}^{1}$ and $\mathrm{x}^{2}$ to obtain:

$$
\begin{aligned}
& \mathrm{P}_{2}=-\frac{\mathrm{f}}{2 \beta} \equiv \vartheta ; \mathrm{P}_{3}=-\frac{g p_{1}}{6 \beta} \equiv \vartheta_{0} ; \mathrm{P}_{1} \\
& \mathrm{P}_{4}=-\frac{\mathrm{gp}_{2}-\mathrm{hP}_{1}^{2}}{12 \beta} \equiv \vartheta_{2} \mathrm{P}_{1}^{2}+\vartheta_{3}
\end{aligned}
$$

Where:

$$
\begin{aligned}
& \mathrm{f}=\mathrm{aa}_{0}^{\mathrm{n}} ; \mathrm{g}=\mathrm{ana}_{0}^{\mathrm{n}} ; \mathrm{h}_{1}=\infty \frac{\mathrm{n}(\mathrm{n}-1)}{2} \mathrm{a}_{0}^{\mathrm{n}-2} \mathrm{~b}_{0}^{2}-\mathrm{ana}_{0}^{\mathrm{n}-1} \mathrm{~b}_{0} ; \\
& \mathrm{j}=\frac{\mathrm{n}(\mathrm{n}-1)}{2} \mathrm{a}_{0}^{\mathrm{n}-2} \mathrm{~b}_{0}^{2} ; \vartheta=-\frac{\mathrm{f}}{2 \beta} ; \vartheta_{1}= \\
& -\frac{\mathrm{g}}{6 \beta} ; \vartheta_{2}=\frac{-\mathrm{h}}{12 \beta} ; \vartheta_{3}=\frac{-\mathrm{gp}_{2}}{12 \beta}
\end{aligned}
$$

Substituting the compressed forms of $\mathrm{P}_{2}, \mathrm{P}_{3}$ and $\mathrm{P}_{4}$ in (27) into (26) subject to (25), the quadratic equation obtained is: $\vartheta_{2} a^{4} p_{1}^{2}+\left(a+\vartheta_{1} a^{3}\right) p_{1}+\vartheta a^{2}+\vartheta_{3} a^{4}-h=0$

The values of $\mathrm{P}_{1}$ obtained from (29) above are used in (27) to find the solution to the inner region.

Similarly for the second region, the steady state Penne's bio heat equation to be solved is:

$\beta \frac{d T}{d x^{2}}+\left(a_{0}+b_{0} T\right)^{n}(1-T)+\lambda T=0$

$\mathrm{T}(\mathrm{a})=\mathrm{h} \quad \mathrm{T}(1)=\frac{\mathrm{T}_{\mathrm{c}}}{\mathrm{T}_{\mathrm{b}}}$

A solution is sought for the outer region:

$\mathrm{T}^{0}=\sum_{\mathrm{i}=1}^{\infty} \mathrm{q}_{\mathrm{i}}(1-\mathrm{x})^{\mathrm{i}} \quad \mathrm{a}_{\mathrm{i}} \leq \mathrm{x} \leq \mathrm{U}_{\mathrm{i}}$

Subject to (31): Introducing (32) into (30), comparing and comparing the coefficients of, $\operatorname{Order} Z^{0}, Z$ and $Z^{2}$ :

$$
\begin{aligned}
\mathrm{q}_{2} & =\frac{\mathrm{Jq}_{0}^{3}-\mathrm{hq}_{0}^{2}-(\mathrm{g}+\lambda) \mathrm{q}_{0}-\mathrm{f}}{2 \beta} \equiv \partial \\
\mathrm{q}_{3} & =\frac{3 \mathrm{Jq}_{0}^{2}-2 \mathrm{hq}_{0}-(\mathrm{g}+\lambda) \mathrm{q}_{1}}{6 \beta} \equiv \partial_{1} \mathrm{q}_{1} \\
\mathrm{q}_{4} & =\frac{\left(3 \mathrm{Jq}_{0}^{2}-2 \mathrm{hq}_{0}\right)-(\mathrm{g}+\lambda) \mathrm{q}_{2}+\left(3 \mathrm{Jq}_{0}-\mathrm{h}\right) \mathrm{q}_{1}^{2}}{12 \beta} \\
& \equiv \partial_{2} \mathrm{q}_{1}^{2}+\partial_{3}
\end{aligned}
$$

Where:

$$
\begin{aligned}
& \mathrm{f}=\mathrm{a}_{0}^{\mathrm{n}} ; \mathrm{g}=\mathrm{ana}_{0}^{\mathrm{n}-1} ; \\
& \mathrm{h}_{1}=\mathrm{a} \frac{\mathrm{n}(\mathrm{n}-1)}{2} \mathrm{a}_{0}^{\mathrm{n}-2} \mathrm{~b}_{0}^{2}-\mathrm{ana}_{0}^{\mathrm{n}-1} \mathrm{~b}_{0} ; j=\frac{\mathrm{n}(\mathrm{n}-1)}{2} \mathrm{a}_{0}^{\mathrm{n}-2} \mathrm{~b}_{0}^{2} ; \\
& \vartheta=\frac{\mathrm{Jq}_{0}^{3}-\mathrm{hq}_{0}^{2}-(\mathrm{g}+\lambda) \mathrm{q}_{0}-\mathrm{f}}{2 \beta} ; \vartheta_{1}= \\
& \frac{3 \mathrm{Jq}_{0}^{2}-2 \mathrm{hq}_{0}-(\mathrm{g}+\lambda)}{6 \beta} ; \vartheta_{2}=\frac{3 \mathrm{Jq}_{0}-\mathrm{h}}{12 \beta} ; \vartheta_{3} \\
& =\frac{3 \mathrm{Jq}_{0}^{2}-2 \mathrm{hq}_{0}-(\mathrm{g}+\lambda) \mathrm{q}_{2}}{12 \beta} ; \mathrm{Z}=1-\mathrm{x}
\end{aligned}
$$

Equation 33 is substituted into (32) for (30) the resulting quadratic equation is:

$$
\begin{aligned}
& {\left[(1-a)^{3} \partial_{0} \partial_{2}+(1-a)_{3} \partial_{3}\right] q_{1}^{3}+(1-a)^{2} \partial_{0} q_{1}^{2}+} \\
& \left((1-a)+(1-a)^{3} \partial_{1}\right) q_{1}+ \\
& (1-a)^{2} \partial+(1-a)^{4} \partial_{3}+q_{0}-h=0
\end{aligned}
$$


The two values of $\mathrm{q}_{1}$ obtained from (35) are then substituted into (32) to find the temperature for the outer region.

\section{RESULTS AND DISCUSSION}

Graphs of steady states of the governing equations for a multilayered model (temperature dependent blood perfusion when $\mathrm{m}=1$ ) are displayed below.

Case 1: Figure 2-4 show the various points at which there is rise and fall in temperature for the different arrangements of the thermal conductivities within each layer of the heterogeneous tissue.

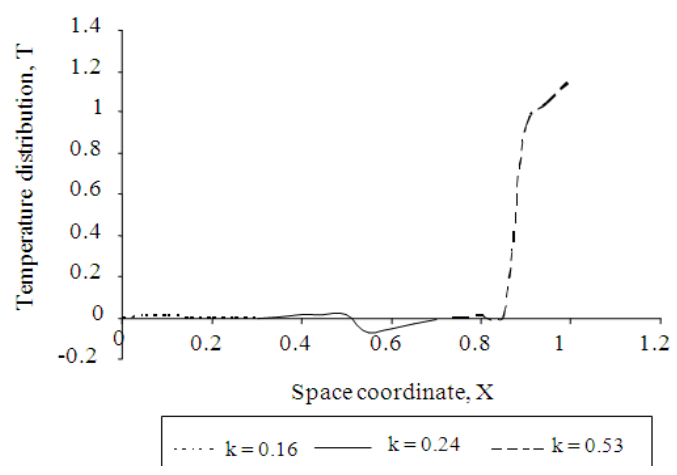

Fig. 2: Temperature distribution, against the space coordinate, $\mathrm{x}$ for a multilayer solution of temperature dependent perfusion, $\mathrm{w}$; where $\mathrm{n}=$ $2, \mathrm{a}_{0}=1, \mathrm{~b}_{0}=1, \mathrm{E}_{0}=1, \mathrm{C}_{\mathrm{b}}=3770, \mathrm{C}_{\mathrm{p}}=3590$, $\mathrm{w}_{\mathrm{b}}=0.00125, \mathrm{~g}=1050$ and $\mathrm{g}_{\mathrm{b}}=1060$. (Matching at three points, $0.15,0.5$ and 0.85 )

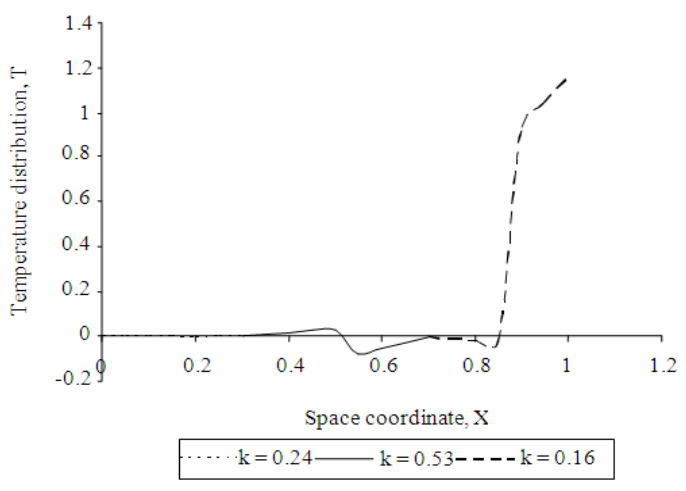

Fig. 3: Temperature distribution, against the space coordinate, $\mathrm{x}$ for a multilayer solution of temperature dependent perfusion, $\mathrm{w}$; where $\mathrm{n}=$ $2, \mathrm{a}_{0}=1, \mathrm{~b}_{0}=1, \mathrm{E}_{0}=2, \mathrm{C}_{\mathrm{b}}=3770, \mathrm{C}_{\mathrm{p}}=3590$, $\mathrm{w}_{\mathrm{b}}=0.00125, \mathrm{~g}=1050$ and $\mathrm{g}_{\mathrm{b}}=1060$. (Matching at three points, $0.15,0.5$ and 0.85 )

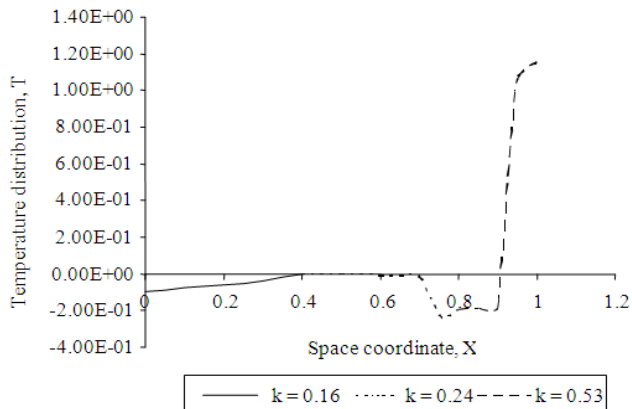

Fig. 4: Temperature distribution the space coordinate, $\mathrm{x}$ for a multilayer solution of $\mathrm{w}=(\mathrm{a}+\mathrm{bT})^{\mathrm{n}}$, where $\mathrm{n}=2, \mathrm{a}_{0}=1, \mathrm{~b}_{0}=1, \mathrm{E}_{0}=2, \mathrm{C}_{\mathrm{b}}=3770, \mathrm{C}_{\mathrm{p}}=$ $3590, \mathrm{w}_{\mathrm{b}}=0.00125, \mathrm{~g}=1050$ and $\mathrm{g}_{\mathrm{b}}=1060$. (Matching at three points, $0.3,0.7$ and 0.9 for $\mathrm{u}=0.4$ and $\mathrm{v}=0.8$ )

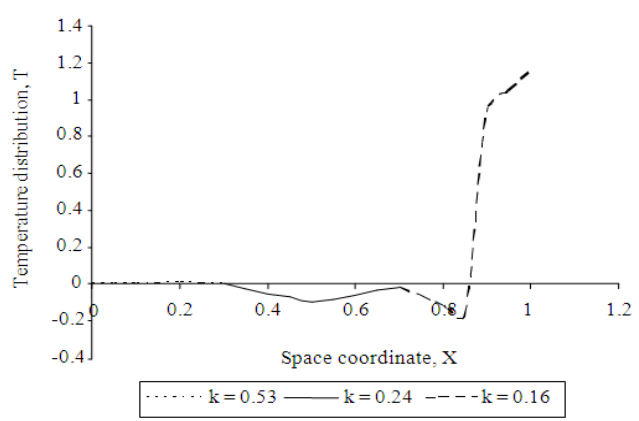

Fig. 5: Temperature distribution, $\mathrm{T}$ against the space coordinate, $\mathrm{x}$ for a multilayer solution of temperature dependent perfusion, $\mathrm{w}$; where $\mathrm{n}=2, \mathrm{a}_{0}=1, \mathrm{~b}_{0}=1, \mathrm{E}_{0}=2, \mathrm{C}_{\mathrm{b}}=3770, \mathrm{C}_{\mathrm{p}}=$ $3590, \mathrm{w}_{\mathrm{b}}=0.00125, \mathrm{~g}=1050$ and $\mathrm{g}_{\mathrm{b}}=1060$. *(Matching at one point, 0.15)

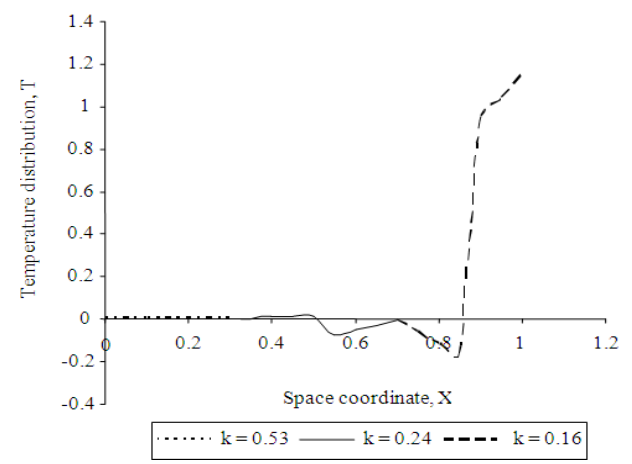

Fig. 6: Temperature distribution, $\mathrm{T}$ against the space coordinate, $\mathrm{x}$ for a multilayer solution of temperature dependent perfusion, $\mathrm{w}$; where $\mathrm{n}=2, \mathrm{a}_{0}=1, \mathrm{~b}_{0}=1, \mathrm{E}_{0}=2, \mathrm{C}_{\mathrm{b}}=3770, \mathrm{C}_{\mathrm{p}}=$ $3590, \mathrm{w}_{\mathrm{b}}=0.00125, \mathrm{~g}=1050$ and $\mathrm{g}_{\mathrm{b}}=1060$. *(Matching at one point, 0.5) 


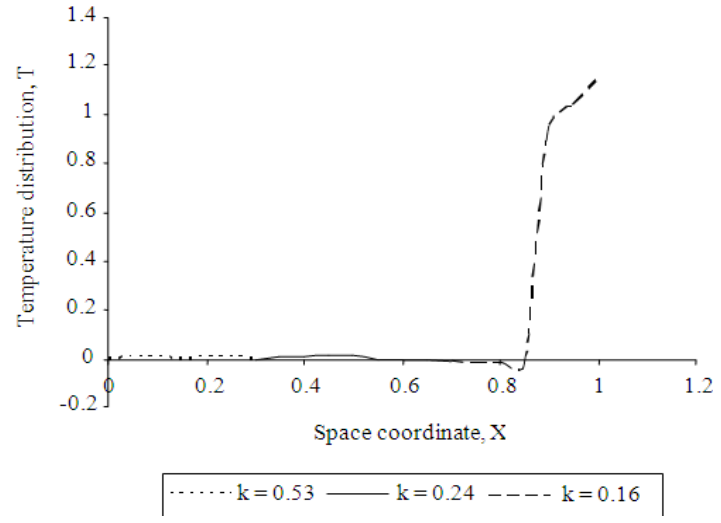

Fig. 7: Temperature distribution, $\mathrm{T}$ against the space coordinate, $\mathrm{x}$ for a multilayer solution of temperature dependent perfusion, $\mathrm{w}$; where $\mathrm{n}=2, \mathrm{a}_{0}=1, \mathrm{~b}_{0}=1, \mathrm{E}_{0}=2, \mathrm{C}_{\mathrm{b}}=3770, \mathrm{C}_{\mathrm{p}}=$ $3590, \mathrm{w}_{\mathrm{b}}=0.00125, \mathrm{~g}=1050$ and $\mathrm{g}_{\mathrm{b}}=1060$. *(Matching at one point, 0.85 )

Case II: The graphs for this heating approach are displayed in Fig. 5-7. The pattern of heat response as the thermal conductivity is being varied is evident in each of the graphs.

\section{CONCLUSION}

A great care and adequate knowledge of tissues properties must be known before adopting a treatment procedure.

\section{REFERENCES}

Adebile, E.A., B.N. Akintewe, O.K. Olaleye and V. Idoko, 2006. Self similar solution for coupled electromagnetic model during microwave heating of biological tissues. J. Niger. Assoc. Math. Phys., 10: 229-234.

http://www.nampjournals.org/abstractvol10.htm

Adebile, E.A., B.N. Akintewe and K.M. Owolabi, 2008. A coupled mathematical model for a temperature dependant blood perfusion in homogenous biological tissues during microwave heating. J. Niger. Assoc. Math. Phys., 13: 183-188. http://www.nampjournals.org/abstractvol13/abtract _vol13.pdf
Adebile, E.A. and B.N. Akintewe, 2006. On the steady state temperature profiles of biological tissues during microwave heating. J. Niger. Assoc. Math. Phys., $\quad 10$ : 223-228. http://www.nampjournals.org/abstractvol10.htm

El-Dabe, N.T.M. M.A.A. Mohammed and A.F. El-Sayed, 2003. Effects of microwave on the thermal states of biological tissue. Afr. J. Biotechnol., 2: 453-459. http://www.academicjournals.org/AJB/abstracts/.../ El-Dabe\%20et\%20al.htm

Gowrishankar, T.R., D.A. Stewart, G.T. Martin and J.C. Weaver, 2004. Transport lattice models of heat transport in skin with spatially heterogeneous temperature dependent perfusion. Biomed. Eng. J. Online, 3: 1-42.

http://www.bioelectromagnetics.org/doc/bems2006 -abstracts.pdf

Hwang, S.C. and D. Lemmonier, 1995. Coupling numerical solution of bio heat transfer equation and Maxwell's equations in biological tissues during hyperthermia. Trans. Wessex Inst. Biomed. Health, 2: 8. DOI: 10.2495/BIO950511

Kulikov, K.G., 2009. The modeling of the temperature field formed inside multilayered biological tissue under laser emission. Prog. Biomed. Opt. Imag., 10: 73731R-1-73731R.

Liu, Z., M. Ahmed, A. Sabir, S. Humpries and S.N. Goldberg, 2007. Computer modeling of the effect of perfusion on heating patterns in radiofrequency tumor ablation. Int. J. Hyperthermia, 23: 49-58. DOI: 10.1080/02656730601094415

Mahjoob, S. and K. Vafai, 2010. Analysis of bioheat transport through a dual layer biological media. J. Heat Transfer, 132: 031101-031114. DOI: 10.1115/1.4000060

Ting-Bo, F., L. Zhen-Bo, Z. Zhe, Z. Dong and G. XiuFen, 2009. Modeling of nonlinear propagation in multi-layer biological tissues for strong focused ultrasound, Chinese. Phys. Lett., 26: 084302.

Xu, F., T.J. Lu, K.A. Seffen and E.Y.K. Ng, 2009. Mathematical modeling of skin bioheat. Transfer Applied Mech. Rev., 62: 050801-050835. DOI: 10.1115/1.3124646 